year he was elected to a Prize fellowship in his own College, Trinity, which he held until his appointment to the Department of Zoology in Edinburgh in 1953. Dr. Mitchison has also accepted several invitations to pursue his research overseas. In particular, he worked as a research associate at the University of California, Berkeley, in 1957, while holding a Carnegie travel fellowship, and in 1960 he was appointed visiting professor at the Marine Biological Station, Wood's Hole. Throughout this period, Dr. Mitchison's principal research interest has lain in the field of cell biology.

\section{British Committee on Chemical Education}

Prof. R. A. Morton, professor of biochemistry in the University of Liverpool, has been appointed the first chairman of the new British Committee on Chemical Education, established jointly by the Royal Society and the Royal Institute of Chemistry. This Committee comprises nominees from the Royal Society, Royal Institute of Chemistry, Chemical Society, Society of Chemical Industry, Science Masters' Association, Association of Women Science Teachers, Ministry of Education and the Scottish Edueation Department, together with several persons who have been invited to serve in their personal capacity but with special reference to their experience in diverse fields of chemical education. The secretary of the Committee is Mr. D. G. Chisman, Education Officer, Royal Institute of Chemistry, 30 Russell Square, London, W.C.1. One of the main functions of the new Committee will be to co-ordinate and make more widely known the various developments that are taking place in chemical education and generally to disseminate information on what is happening in different spheres of chemical education in Britain and overseas.

At the first meeting of the British Committee, preliminary consideration was given to the function of examinations in chemistry at school-level, especially in the light of the new approach to the teaching of chemistry that is being developed as part of the project for the improvement of school science and mathematics curricula, sponsored by the Nuffield Foundation. The desirability of ensuring that questions set in public examinations are in harmony with the new approach to the teaching of chemistry was stressed, and to this end the Committee hopes to establish co-operation and sympathy with the General Certificate of Education Examining Boards, many of whom are known to be revising their chemistry syllabuses at the present time.

\section{Atomic Energy at Capenhurst and Aldermaston}

IN an adjournment debate in the House of Commons on November 19 on the Atomic Energy Establishment, Capenhurst, the Parliamentary Secretary for Science, Mr. D. Freeth, repeated his previous assurance that the reduction of output to the minimum level to keep the plant in production was being effected by a phased process over about 18 months. The level of activity at Aldermaston was unlikely to change significantly over the next 18 months or so.

\section{Commonwealth Scholarships and Bursaries}

IN a written answer for the Secretary for Technical Co-operation in the House of Commons on November 22, Mr. Iain Macleod stated that attendance at the introduction courses for overseas students arranged each autumn by the British Council, including special courses in London for Commonwealth scholars and bursars, had doubled within the past three years. The Council encouraged institutions of higher education to arrange their own courses and would do all it could in co-operation with the educational authorities to extend this work. Under the Commonwealth Teacher Training Bursary Scheme, Britain had awarded 97 bursaries leading to a technical teacher qualification, and 54 bursars had completed their courses. Under a new scheme announced at the second Commonwealth Education Conference, 40-50 bursaries would be awarded annually for teachers of eraft subjects, students attending a technical college for six months, and after six months practical training in industry, spending a second year in a technical teacher training college. The first intake of bursars would be offered courses in mechanical engineering, electrical engineering, constructional engineering and building. Every encouragement was being given to postgraduate scholars in science and technology to take advantage of part-time teacher training courses.

\section{The U.S. National Science Foundation}

AN admirably illustrated brochure recently issued describes briefly but clearly the many-sided activities of the National Science Foundation (National Science Foundation. Pp. 32. Washington, D.C.: National Science Foundation, 1962). The way in which the Foundation supports research, its varied programmes in support of education in the sciences, its work in the field of scientific information, in assessing the potential and need for national research and its support for international scientific activities are summarized. Included also are an outline of the organization of the Foundation and a brief list of publications giving further information on particular activitios.

\section{Scientific Research in Schools}

ThE fifth annual report of the Royal Society Com. mittee on Scientific Research in Schools indicates the progress being made by the Royal Society to foster scientific research projects by science teachers in schools. During the year covered by the report, the number of research projects increased to seventy, involving sixty-one schools. This represents an increase of seven projects and five schools over the fourth report. The Council of the Royal Society again made available a grant of $£ 2,000$ for the provision of special equipment and apparatus. During the year, the U.K. Atomic Energy Authority offered the Committee a grant of up to $£ 1,000$ per annum for the purpose of providing grants to school science teachers requiring special equipment to pursue research of interest to the Authority: the first contribution by the Authority will be made early in 1963. A gift is also acknowledged of $£ 105$ from Griffin and George, Ltd., which is to be transferred to the Science Masters' Association for the development of laboratory apparatus for schools. All the work included in the various projects was carried out with the specialist advice and assistance of Fellows of the Royal Society and of others, all of whom have generously given their help, and the Committee gratefully acknowledges the valuable help given by these advisers. Five papers have been published in learned publications by science teachers concerned with projects supported by the Committee. Appended to the report is a list of the science teachers concerned with their scientific research projects, arranged alphabetically according to schools. 